\title{
Evaluasi Program Supervisi Akademik di PAUD Swasta
}

\author{
Daniel Kurniawan \\ Magister Manajemen Pendidikan Universitas Kristen Satya Wacana \\ michael.daniel.kurniawan@gmail.com \\ Yari Dwikurnaningsih \\ Magister Manajemen Pendidikan Universitas Kristen Satya Wacana \\ yari.dwikurnaningsih@staff.uksw.edu \\ Bambang Suteng Sulasmono \\ Magister Manajemen Pendidikan Universitas Kristen Satya Wacana \\ bambang.sulasmono@staff.uksw.edu
}

\begin{abstract}
This study was designed to evaluate academic supervision program at PAUD Tunas Kasih, Magelang, using Context, Input, Process, Product (CIPP) evaluation model. The results of the study were expected to provide inputs to decision-makers for subsequent programs. The respondents of this descriptive-qualitative research included the school principal, six teachers, and a school managerial staff. Data collection was done through interviews, observation and document studies. Triangulation of data sources and methods validated the data, subsequently analysed through data condensation, data display, conclusion drawing and verification. Findings indicated the context evaluation revealed a need for academic supervision based on the condition and the need for teacher's quality improvement. The input evaluation described the well-planned program-using different techniques, involving the teachers in their readiness, supported by available budget and infrastructure. The process evaluation reported the implementation of the planned techniques, with some adjustments based on the on-going condition, supported by the teachers' readiness as well as participation and how they handle the constraints. The product evaluation found out that the academic supervision program had positive impacts and achieved the planned goals. It also discovered teachers' positive responses and some follow-up plans. Lastly, this study gave recommendations to improve the local supervision programs, inputs to the school management, and ideas for future researches.
\end{abstract}

Keywords: Academic Supervision, CIPP, Program Evaluation

\section{Article Info}

Received date: 10 Desember $2018 \quad$ Revised date: 12 Desember $2018 \quad$ Accepted date: 17 Desember 2018

\section{PENDAHULUAN}

Guru memiliki peran yang penting dalam menentukan kualitas dan keberhasilan pendidikan sebuah sekolah (Arikunto, 2012; Arikunto \& Yuliana, 2012; Kartono, 2009; Mette, Range, Anderson, Hvidston, \& Nieuwenhuizen, 2015, Stronge, Richard, \&
Catano, 2013; Sarfo \& Cudjoe, 2016). Selain itu, penelitian menemukan bahwa guru yang mengajar dengan efektif berdampak pada pencapaian siswa (Aaronson, Barrow, \& Sander, 2007; Garrett \& Steinberg, 2015; Mette et al., 2015; Rockoff, 2004). Oleh karena itu, diperlukan upaya untuk menjamin kualitas guru 
Kelola: Jurnal Manajemen Pendidikan, Vol. 5, No. 2, Juli-Desember 2018

tersebut, dan supervisi pendidikan menyediakan fungsi penjaminan mutu pembelajaran, termasuk mutu guru.

Supervisi pendidikan berupaya menjamin dan mengembangkan kualitas dan kinerja guru. Brown (2002) setuju bahwa supervisi pendidikan bertujuan mengembangkan dan meningkatkan kualitas pendidikan yang nantinya juga akan berkontribusi pada pencapaian siswa yang lebih baik. Supervisi merupakan proses sepanjang guru masih berkarir di dunia pendidikan (Arikunto \& Yuliana, 2012) dan berperan penting untuk meningkatkan proses pembelajaran dengan usaha membina sekolah, termasuk para guru (Pidarta, 2009; Suhardan, 2010). Istilah supervisi sendiri tidak perlu dipusingkan ketika istilah ini sering digantikan atau disamakan dengan 'pengawasan', 'penilikan', 'pemeriksaan', dan 'inspeksi' (Mulyasa, 2012; Arikunto \& Yuliana, 2012). Namun demikian, Arikunto \& Yuliana mengingatkan bahwa istilah-istilah selain supervisi tersebut lebih menekankan pada pemeriksaan yang berfokus pada kekurangan dan kesalahan. Perlu digarisbawahi juga bahwa supervisi dilaksanakan bukan semata-mata sebagai pemenuhan tugas manajerial pimpinan sekolah, supervisor atau administrator, namun lebih bertujuan mengembangkan mutu para guru serta kualitas dan produktivitas sekolah (Mette et al., 2015; Minarti, 2011; Stronge et al. 2013).

Dilihat dari obyek supervisi, terdapat tiga jenis supervisi pendidikan, yaitu (1) supervisi akademik, yang berkaitan langsung dengan kegiatan belajar-mengajar dan berfungsi untuk memperbaiki dan meningkatkan kualitas pengajaran, supervisi administrasi-dilakukan terhadap administrasi yang mendukung kegiatan KBM, dan (3) supervisi kelembagaan atau institusi, dengan lingkup sekolah secara lembaga yang lebih luas, termasuk kurikulum, personel atau ketenagakerjaan, ketatausahaan atau administrasi sekolah, sarana prasarana, humas sekolah, dan kerja sama lainnya untuk pengembangan sekolah.

Sebagai bagian dari supervisi pendidikan, supervisi akademik mengusahakan adanya pengembangan diri dan perbaikan kualitas guru yang akhirnya bertujuan untuk meningkatkan mutu pendidikan (Egwu, 2015; Mukhtar \& Iskandar, 2009; Sarfo \& Cudjoe, 2016; Suhardan, 2010). Supervisi tidak bertujuan untuk sekedar mengevaluasi dan mencari kekurangan atau kesalahan para guru, namun lebih kepada membimbing mereka dan mengembangkan proses mengajar yang menjadi tugasnya (Memduhoglu, 2012, Suhardan, 2010, Tatang, 2016). Ada beberapa teknik supervisi akademik, baik yang bersifat individu - seperti kunjungan kelas, observasi kelas, percakapan atau pertemuan individual, self-evaluation, supervisi klinis-maupun kelompok, termasuk pertemuan orientasi, rapat guru, studi atau diskusi kelompok antar guru, lokakarya atau seminar, kunjungan antar sekolah atau studi banding, bulletin supervisi dan learning resource centre (Mulyasa, 2012; Umiarso dan Gojali, 2010; Priansa \& Setiana, 2018; Imron, 2011; Pidarta, 2009).

Supervisi pendidikan, dan supervisi akademik, dilaksanakan di semua jenjang pendidikan di Indonesia, termasuk di tingkat pendidikan anak usia dini. Minat dan sorotan terhadap pentingnya Pendidikan Anak Usia Dini (PAUD) sendiri makin meningkat di Indonesia. Makin tinggi partisipasi masyarakat Indonesia dalam pendidikan anak usia dini, meskipun ada perbedaan tingkat partisipasi orang tua dari latar belakang ekonomi yang berbeda (Alatas, 2013). PAUD di Indonesia mencoba menghadapi tantangan terhadap perkembangan anak dalam domain bahasa, keterampilan kognisi, kematangan emosi, komunikasi juga pengetahuan umum. Suryadarma \& Jones (2013) mengemukakan dua alasan untuk fenomena tersebut. Pertama, adanya kesadaran bahwa kesuksesan terhadap 
proses pendidikan di kemudian hari berakar dari layanan PAUD. Selain itu, PAUD menolong upaya penyamarataan titik mulai bagi pendidikan dasar siswa-siswi, terkhusus untuk anak-anak dari latar belakang yang rendah.

Oleh karena itu, penjaminan terhadap layanan mutu pendidikan anak usia dini juga perlu diupayakan. Permendikbud No. 137, Tahun 2014 tentang Standar Nasional PAUD menuliskan di Pasal 17 bahwa pengawasan pembelajaran juga perlu dilakukan untuk memberikan 'penilaian dan/atau pengarahan dalam perencanaan dan pelaksanaan pembelajaran'. Teknik pengawasan pembelajaran yang digunakan adalah supervisi, dan salah satu tugas manajerial kepala lembaga PAUD adalah pelaksanaan supervisi.

Berada di bawah naungan Yayasan Perguruan Kristen Indonesia (YPKI) Magelang, PAUD Tunas Kasih merupakan salah satu lembaga swasta penyelenggara pendidikan anak usia dini di Kota Magelang. Secara struktur organisasi, PAUD Tunas Kasih berada di bawah Manajemen Operasional YPKI Magelang, yang memiliki fungsi pengelolaan terhadap kegiatan operasional harian sekolahsekolah di bawah YPKI Magelang. PAUD Tunas Kasih memiliki beberapa program, yaitu kelompok bermain (untuk anak usia 2-3 tahun) dan taman kanak-kanak (untuk usia 4-5 tahun). Mulai tahun 2017, layanan penitipan anak dibuka dengan nama Full-Day School (FDS) Tunas Kasih, Magelang, yang menerima anak mulai usia satu sampai dengan lima tahun.

Kegiatan pengawasan, baik secara luas terhadap layanan pendidikan maupun spesifik yang dilakukan terhadap para pegawai, termasuk guru, direncanakan dan dilaksanakan dengan rutin di PAUD Tunas Kasih. Secara khusus, kepala sekolah memiliki tanggung jawab untuk mengelola dan melaksanakan program supervisi akademik. Wawancara dan observasi prastudi menemukan bahwa beberapa teknik supervisi akademik sebenarnya telah dilaksanakan, termasuk observasi kelas, konferensi, seminar dan lokakarya, studi banding, dan kelompok kerja guru. Selain itu terdapat laporan yang menunjukkan tingkat kepercayaan kepada kualitas para guru di PAUD Tunas Kasih, salah satunya dengan adanya studi banding dari instansi ataupun kepala sekolah lain yang datang untuk belajar di PAUD Tunas Kasih. Ini mendorong perlu diadakannya evaluasi terhadap program supervisi akademik, dengan kenyataan bahwa sejak awal dituntut diadakannya supervisi akademik oleh Pengurus YPKI Magelang di sekolah-sekolah yang dinaunginya, termasuk PAUD Tunas Kasih, program supervisi akademik belum pernah dievaluasi.

Untuk mengetahui ketercapaian dan keberhasilan suatu program diperlukan adanya evaluasi-yang menurut Arikunto dan Jabar (2010), Munthe (2015) dan McMillan (2008) merupakan proses pencarian dan pengumpulan informasi secara sistematis, mengenai kinerja sesuatu dengan membandingkan kriteria serta tujuan yang telah ditetapkan. Fitzpatrick, Sanders, dan Worthen (2012) menekankan bahwa tujuan utama evaluasi adalah meninjau nilai atau kepantasan/kelayakan obyek yang dievaluasi-berupa kebijakan, program atau produk, yang berakibat hasil evaluasi tersebut bersifat spesifik pada obyek dan lokasinya, seperti digarisbawahi McMillan (2008).

Penelitian ini bertujuan mengevaluasi program supervisi akademik di PAUD Tunas Kasih, Magelang, berdasarkan aspek context, input, process dan product. Model evaluasi Context, Input, Process and Product (CIPP) digunakan dalam penelitian ini. Model evaluasi CIPP dipilih karena berorientasi pada keputusan (decision-oriented) (Fitzpatrick, Sanders, \& Worthen, 2012), sehingga hasil penelitian evaluatif ini diharapkan dapat memberikan rekomendasi kepada pemimpin atau pengelola PAUD Tunas Kasih, Magelang. Pada sisi lain, evaluasi model CIPP memiliki keunggulan yaitu memiliki pendekatan yang 
Kelola: Jurnal Manajemen Pendidikan, Vol. 5, No. 2, Juli-Desember 2018

bersifat holistik dalam proses evaluasinya dan lebih komprehensif dibandingkan dengan model evaluasi lainnya (Dwikurnaningsih, 2017). Terhadap kebijakan berhubungan dengan supervisi akademik di lembaga pendidikan tersebut, hasil penelitian ini dapat digunakan sebagai pertimbangan masukan apakah program tersebut dilanjutkan, dilanjutkan dengan perubahan, atau tidak dilanjutkan (Sukardi, 2008).

\section{METODE PENELITIAN}

Penelitian evaluatif ini menggunakan pendekatan kualitatif dan bersifat deskriptif. Program supervisi akademik yang dilaksanakan tahun pelajaran 2017/2018 menjadi obyek evaluasi. Data dikumpulkan dengan melibatkan kepala sekolah sebagai supervisor, para guru (termasuk guru senior dan yunior, terdiri dari empat guru di jenjang Taman Kanak-Kanak dan dua guru dari Kelompok Bermain), serta satu staff manajemen sekolah YPKI Magelang. Lembaga PAUD tersebut dipilih karena alasan fisibilitas penelitian; peneliti pernah bekerja sebagai staf manajerial di kantor Manajemen Operasional YPKI Magelang yang mengelola TK Tunas Kasih, Magelang.

Pengumpulan data dilakukan melalui interview, observasi, dan studi dokumen, mengingat bahwa penelitian ini bersifat evaluatif dan kualitatif (Wiersma dan Jurs, 2009). Wawancara sistematik yang mendalam melibatkan kepala sekolah, enam orang guru dan satu orang staff manajemen sekolah dan bersifat semi terstruktur. Fleksibilitas bertanyamenjawab dimungkinkan, namun tetap dalam kontrol dengan pedoman wawancara yang telah dipersiapkan. Dialog direkam dengan aplikasi perekam suara dalam ponsel peneliti. Observasi langsung dilaksanakan, di mana peneliti mengambil peran non-participant observer. Observasi dilakukan antara lain di dalam ruang kelas, ketika kegiatan observasi kelas dilaksanakan, juga dalam rapat guru dan seminar. Baik descriptive maupun reflective fieldnotes disusun untuk mencatat temuan di lapangan atau dalam kegiatan yang diamati. Studi dokumen dilakukan terhadap dokumendokumen penunjang, meliputi dokumen kurikulum sekolah, program supervisi, catatan dan bukti-bukti perencanaan dan pelaksanaan kegiatan/ teknik supervisi, laporan hasil dan dokumentasi kegiatan, laporan rencana tindak lanjut dan notula/catatan rapat dan kegiatan sekolah.

Mempertimbangkan faktor batasan waktu dan jumlah informasi dan data yang perlu dikumpulkan, penelitian ini dibatasi pada beberapa aspek/komponen evaluasi yang fisibel dan mewakili untuk mengusahakan evalusi CIPP yang komprehensif. Berdasarkan tahap evaluasi CIPP, beberapa aspek/komponen supervisi akademik yang berbeda, sumber data, teknik dan instrumen pengumpulan data, dirincikan dalam tabel berikut.

Triangulasi sumber dan triangulasi teknik pengumpulan data dilakukan untuk menjamin keabsahan data serta kedalaman dan kejelasan pemahaman evaluasi. Data kualitatif yang telah dikumpulkan dianalisa sebelum disajikan dan dibahas. Analisa data bersifat deskriptif dan dilakukan berdasar kelompok tahap evaluasi CIPP. Terdapat tiga tahap analisa data yang saling terhubung (Miles, Huberman, \& Saldana, 2014) dalam penelitian ini: (1) kondensasi data, (2) penyajian data, dan (3) pengambilan dan verifikasi kesimpulan.

\section{HASIL PENELITIAN DAN PEMBAHASAN}

\section{Hasil Penelitian}

\section{Evaluasi Konteks}

Terdapat kerancuan

atau kesalahpahaman dari kepala sekolah maupun para guru PAUD Tunas Kasih, Magelang terhadap konsep dan definisi supervisi akademik. Pemahaman supervisi akademik mereka terbatas pada observasi kelas yang dianggap sebagai satu-satunya teknik supervisi akademik. Observasi yang diadakan juga 
Evaluasi Program Supervisi Akademik di PAUD Swasta | Daniel Kurniawan, dkk.

dipahami sebagai tuntutan kelengkapan penilaian dan evaluasi pegawai. Akibatnya, supervisi akademik dicirikan dengan pengamatan, evaluasi atau penilaian yang dilakukan oleh kepala sekolah dengan fokus pada mengamati kekurangan dan kesalahan guru dalam melaksanakan tugasnya.

Namun demikian, kepala sekolah maupun para guru berpendapat bahwa penilaian atau pengamatan tersebut bertujuan untuk perbaikan atau peningkatan kinerja dan kualitas guru-baik secara individual maupun kolektif (saling mengingatkan dan berbagi)_-juga perbaikan kualitas sekolah. Beberapa opini mengenai tujuan dari supervisi akademik yang dipikirkan mereka, antara lain berhubungan dengan

1. wawasan dan pengetahuan pedagogis,

2. keterampilan mengajar, meliputi variasi metode mengajar pengelolaan kelas, strategi penanganan dan pendampingan anak yang efektif, dan penanaman nilainilai kristiani dalam pembelajaran

3. penyusunan administrasi penunjang pembelajaran,

4. penyamaan persepsi antara kepala sekolah dengan guru dan memberi-kan fungsi controlling terhadap penerapan atau pelaksanaan kesepakatan maupun prosedur.

Mengenai dasar hukum atau aturan, kepala sekolah menyebutkan adanya pedoman dari dinas pendidikan dan menyadari tugas supervisi yang dimilikinya, namun belum mempelajari pedoman supervisi akademik dengan lebih rinci. Secara interen, manajemen sekolah menuntut diadakannya kegiatankegiatan pengembangan kualitas guru, melalui observasi kelas, penilaian diri, pembinaan atau pelatihan bagi para kepala sekolah maupun guru, dan rapat-rapat interen. Namun itu tidak tertulis secara jelas dalam buku peraturan kepegawaian atau pedoman interen manapun, meski disampaikan dalam wawancara dengan staff manajemen.
Beberapa kebutuhan dan kondisi di PAUD Tunas Kasih mendorong perlu diadakannya supervisi akademik, yaitu

1. peningkatan kualitas pembelajaran

2. upgrade kualitas para guru, untuk mengupayakan inovasi pembelajaran dan menghadapi perkembangan yang ada

3. perubahan karakteristik dan heterogenitas siswa setiap tahunnya

4. ketidakkonsistenan dalam melak-sanakan prosedur atau kesepakatan bersama, terutama hal-hal yang berhubungan dengan kegiatan belajar-mengajar, seperti pemakaian bahasa dan aturan main dalam kelas; dan

5. masih terdapat guru berlatar belakang nonPAUD yang perlu diperlengkapi secara lebih

\section{Evaluasi Input}

Perencanaan program supervisi akademik di mulai dengan merencanakan dan merancang program kerja sekolah. Kepala sekolah menginisiasi dan menjelaskan rencana yang telah disusun, kemudian mengundang guru untuk memberikan masukan, berupa usulan, ide kebutuhan, atau penjadwalan pelaksanaan kegiatan. Dalam pelaksanaan teknik observasi kelas, kepala sekolah menawarkan rencana jadwal observasi yang perlu dilengkapi guru.

Sebagian besar teknik dituliskan dalam program kerja, namun ada yang tidak tertulis perencanaannya, meskipun diungkap dalam wawancara. Teknik-teknik yang direncanakan dan dituliskan dalam buku program kerja, antara lain:

1. observasi kelas, direncanakan empat kali dalam satu tahun (dua kali setiap semester) untuk masing-masing guru;

2. pelatihan, workshop atau seminar; terdapat dua jenis (1) interen untuk lokal PAUD Tunas Kasih, berhubungan dengan metode BCCT dan penysusunan program pembelajaran; (2) interen untuk lingkup YPKI, yaitu partisipasi pembinaan 
Kelola: Jurnal Manajemen Pendidikan, Vol. 5, No. 2, Juli-Desember 2018

pegawai, dan (3) mengikuti kegiatan dari penyelenggara luar dengan waktu yang menyesuaikan;

3. pertemuan keompok guru, termasuk Kelompok Kerja Guru (KKG), Kelompok Kepala Sekolah (KKS), dan Ikatan Guru TK Indonesia (GKTI);

4. kompetisi guru interen; direnca-nakan dengan fleksibilitas waktu, menyesuaikan ketersediaan waktu; dan

5. studi banding; direncanakan sekali.

Teknik yang direncanakan namun tidak dituliskan dalam buku program kerja meliputi (1) intervisitasi (dan team-teaching), (2) konferensi, (3) learning resource center, dan (4) rapat-rapat.

SDM yang terlibat dalam kegiatankegiatan yang direncanakan tersebut meliputi kepala sekolah maupun para guru. Para guru melaporkan kesiapan mereka, dengan dukungan kerja sama tim, support dari rekan kerja, dan keterbukaan dalam komunikasi. Sementara itu, sebagai supervisor kepala sekolah pernah mengikuti pelatihan dalam hal supervisi pembelajaran yang diadakan interen, namun tidak berkala. Kepala sekolah juga mengikuti kegiatan kelompok guru dan kepala sekolah, serta pernah ikut pelatihan atau seminar dari dinas, namun tidak secara spesifik membahas supervisi pembelajaran. SDM lain yang terlibat adalah pemateri untuk teknik seminar atau pelatihan.

Budget yang direncanakan untuk program supervisi akademik sebagian besar berasal dari sumber dana sekolah (SPP), dan dana bantuan operasional dari dinas. Seorang guru berpendapat perlu inisiatif proaktif juga untuk rencana penggunaan pendanaan pribadi, untuk mendukung pengembangan diri lewat seminar atau pelatihan maupun persiapan dalam terlibat dalam observasi kelas (dengan mempersiapkan alat peraga dan alat bantu edukasi lainnya).

Sarana-prasarana yang direncanakan untuk program supervisi akademik meliputi
LCD proyektor, media pembelajaran atau alat permainan edukatif, dan perlengkapanperlengkapan lain dalam kelas atau di sekolah. Sarana-prasarana yang ada sudah dinilai cukup, meski ada catatan untuk keterbatasan akses internet dan ketersediaan komputer.

\section{Evaluasi Proses}

Berdasarkan rencana yang telah disusun sebelumnya, teknik atau kegiatan dalam program supervisi akademik di PAUD Tunas Kasih, Magelang dalam tahun pelajaran 2017/2018 yang dapat dilaksanakan yaitu,

1. Observasi kelas. Dilaksanakan sesuai rencana, empat kali dalam setahun, namun terjadwal (announced), dan anda masukan dari guru agar observasi tanpa pemberitahuan (unnanouced) juga dilaksanakan untuk memberikan gambaran yang riil. Panduan observasi dari manajemen sekolah juga mendapat catatan perlunya tinjauan ulang.

2. Pelatihan, workshop, dan seminar. Teknik ini dilakukan secara interen, baik untuk lokal PAUD Tunas Kasih dan dalam lingkup YPKI Magelang, ataupun mengikuti penyelenggara dari luar (dinas pendidikan dan instansi lain). Pelatihan interen lokal diadakan sekali, sementara pembinaan dari manajemen sekolah diadakan empat kali. Untuk kegiatan luar, terdapat sembilan kegiatan yang diikuti, termasuk empat lomba/kompetisi guru, dan para guru berkewajiban menyusun laporan tertulis dan men-sharing-kan dengan rekan lain.

3. Pertemuan Kelompok Guru. Forum yang diikuti antara lain KKG, KKS dan IGTKI, dengan jadwal kegiatan menyesuaikan undangan. Selain menjadi peserta ada beberapa kesempatan guru membagikan pengalaman/ best practice dalam pertemuan tersebut.

4. Intervisitasi. Sekalgius menyertakan teknik team-teaching, di mana terdapat dua guru dalam satu kelas, sesuai kondisi 
Evaluasi Program Supervisi Akademik di PAUD Swasta | Daniel Kurniawan, dkk.

metode pembelajaran yang dipakai, sehingga para guru dapat saling mengamati.

5. Konferensi. Konferensi umumnya dilakukan sebelum dan setelah observasi, namun juga dilaksanakan untuk membahas tugas atau tanggung jawab spesifik yang diampu guru, seperti anak usia tertentu, tanggung jawab program dan tugas kepanitiaan.

6. Learning Resource Centre. Teknik ini berupa penyediaan buku referensi penunjang untuk guru serta akses internet untuk mencari materi/ informasi pembelajaran.

7. Rapat. Karena kendala waktu, rapat tidak rutin dilaksanakan. Rapat diadakan berdasarkan urgensi atau prioritas kebutuhan dan topik yang akan dibahas. Sebagai ganti rapat, briefing pagi diadakan, berisi doa, pembacaan artikel rohani, dan pembahasan singkat topik tertentu. Ini masih dirasa bersifat informatif dan terburu-buru, sehingga kurang efektif untuk diskusi yang lebih mendalam. Diskusi siang dalam waktu istirahat, terjadi dan para guru serta kepala skeolah berbagi informasi dan ide serta berkoodinasi. Guru dapat membahas permasalahan yang baru dihadapi di dalam kelas, dibandingkan dengan menunggu jadwal rapat yang lebih formal.

Teknik yang direncanakan namun tidak terlaksana adalah kompetisi guru interen dan studi banding. Ketidakterlaksanaan ini karena faktor kepadatan kegiatan.

Dalam pelaksanaan kegiatan-kegiatan tersebut, kendala yang dihadapi berhubungan dengan jadwal waktu kegiatan yang padat. Prioritas perlu ditetapkan dan penyesuaian (penjadwalan ulang) kegiatan lain juga dilakukan. Perbedaan standar yang dimiliki dalam memberikan penilaian atau evaluasi terhadap observasi disebutkan oleh kepala sekolah sebagai kendala yang dihadapi dalam teknik observasi. Kendala lain adalah persetujuan dari manajemen sekolah, yang dapat mengakibatkan proposal kegiatan dan partisipasi yang diusulkan menjadi ditunda atau malah dibatalkan. Kendala lain datang dari faktor pribadi guru, seperti rasa malas, Lelah, dan tidak fokus, serta kurangnya inisiatif pribadi.

Sarana prasarana yang tersedia diupayakan untuk dimanfaatkan dengan maksimal dalam kegiatan-kegiatan tersebut. Keterbatasan seperti yang telah disebutkan dalam evaluasi input ditangani dengan inisiatif para guru menggunakan peralatan pribadi.

Guru terlibat dan berperan baik sebagai utusan atau peserta (rapat, observasi, seminar) maupun pemateri (dalam pertemuan guru). Keaktifan dan partisipasi guru juga nampak dalam diskusi maupun sharing wawasan dengan rekan dalam briefing. Di sisi lain, kepala sekolah sudah menjalankan peran supervisor dengan cukup baik, dalam mengawal pelaksanaan program, mendorong upaya perubahan, kemajuan, dan perbaikan, menegur dan memberi masukan, memberi kebebasan untuk mengungkapkan ide dan masukan, serta mendelegasikan tugas. Catatan untuk kepala sekolah diberikan berhubungan dengan masukan yang cenderung masih informatif dan administratif, serta ekspektasi yang kurang jelas ditangkap guru.

Kegiatan yang dilaksanakan didokumentasikan dengan cukup baik. Para guru memiliki catatan pribadi mereka, demikian pula kepala sekolah. Foto-foto menjadi koleksi pribadi, dan oleh karenanya perlu dikumpulkan untuk menunjang koleksi foto sekolah. Hasil partisipasi seminar dan kegiatan sejenis disusun oleh guru yang terlibat dan dibagikan kepada rekan-rekan. Kepala sekolah menyusun laporan hasil observasi guru dan menyerahkannya kepada manajemen sekolah. 
Kelola: Jurnal Manajemen Pendidikan, Vol. 5, No. 2, Juli-Desember 2018

\section{Evaluasi Produk}

Dalam wawancara, kepala sekolah dan guru berpendapat bahwa program supervisi akademik efektif dan berdampak. Hasil dan manfaat yang disebutkan para guru antara lain (1) adanya masukan untuk perbaikan, (2) peningkatan kemampuan, wawasan, dan keterampilan mengajar, (3) kontrol dan pengawasan serta penertiban administrasi, (4) adanya koordinasi dalam kerja, (5) teguran yang diberikan ketika salah, (6) terjalinnya jejaring dengan komunitas lain (lewat seminar), (7) peningkatan terhadap kepercayaan, citra dan promosi komunitas sekolah (akibatnya PAUD Tunas Kasih dipercaya menjadi target studi banding instansi maupun individu lain), dan (8) dampak jangka panjang terhadap peningkatan karir dan reputasi guru PAUD Tunas Kasih.

Respon positif juga disampaikan oleh para guru maupun kepala sekolah. Hal ini dipahami karena pemahaman mereka terhadap tujuan supervisi dan dampak yang dirasakan. Respon positif yang diungkapkan juga berhubungan dengan (1) kenyamanan untuk terlibat atau berpartisipasi dan (2) memiliki kesempatan dan kebebasan untuk menyampaikan pendapat dan ide (baik melalui konferensi maupun rapat). Respon sebaliknya yang disampaikan berhubungan dengan (1) keraguan untuk berinisiatif dan berpartisipasikarena merasa masih yunior, (2) kekhawatiran dalam partisipasi seminar, terkhusus jika dilaksanakan di luar kota atau memakan waktu lama, dan (3) ketidakpuasan karena belum/tidak dapat menerapkan hasil pelatihan atau seminar yang diterima. Namun demikian, respon negatif yang terungkap tidak mengganggu pelaksanaan kegiatan yang ada.

Terhadap program secara menyeluruh maupun masing-masing kegiatan, evaluasi dilakukan. Menurut kepala sekolah, evaluasi dilakukan setelah satuan kegiatan berlangsung atau secara sumatif terhadap keseluruhan program kerja di akhir tahun. Sebagai supervisor, kepala sekolah memmberikan evaluasi kegiatan maupun evaluasi terhadap kinerja guru, yang kemudian juga menjadi bahan tindak lanjut. Sementara para guru memberikan masukan untuk kegiatan berhubungan dengan hal-hal teknis seperti pemilihan pemateri seminar dan topik seminar selanjutnya. Beberapa harapan diungkapkan para guru, seperti (1) kelanjutan supervisi akademik, (2) pembimbingan terhadap guru yang berhubungan dengan pembelajaran dalam kelas, (3) keterlibatan dan kepercayaan yang lebih, secara spesifik dalam memimpin atau menjadi pemateri sosialisasi pertemuan orang tua, (4) pelibatan pihak observer selain kepala sekolah-seperti manajemen sekolah atau guru senior-untuk memacu semangat, dan (5) pemenuhan kelengkapan dan ketersediaan sarana prasarana yang masih terbatas.

Program supervisi, yang telah dilaksanakan dan dievaluasi, mendorong adanya tindak lanjut, baik yang direncanakan untuk kemudian hari maupun yang dapat diterapkan segera. Tindak lanjut yang direncanakan antara lain (1) studi banding untuk memperbaharui wawasan, (2) seminar membahas topik-topik dalam peningkatan kapasitas guru, misal penanganan anak bermasalah, dan (3) penyusunan pedoman yang lebih jelas, terutama dalam melaksanakan observasi kelas.

\section{Pembahasan}

\section{Evaluasi Konteks}

Supervisi akademik bertujuan untuk menjamin dan mengembangkan kualitas guru yang berhubungan langsung dengan kegiatan belajar-mengajar (Umiarso \& Gojali, 2010; Mulyasa, 2012:249). Hal serupa telah diungkapkan oleh kepala sekolah maupun guru yang telah memahami bahwa tujuan akhir daripada supervisi akademik adalah peningkatan mutu guru.

Namun demikian, pemahaman awal mengenai makna supervisi akademik masih rancu di PAUD Tunas Kasih, baik dari kepala 
sekolah maupun guru. Kesalahpahaman konsep supervisi akademik juga dilaporkan oleh Merukh \& Sulasmono (2016) dan Widodo (2014a), yang menemukan keterbatasan pemahaman dari kepala sekolah maupun pengawas yang mempengaruhi perencanaan dan pelaksanaan supervisi yang kurang efektif. Zepeda (2006) mengingatkan agar kepala sekolah memandang supervisi lebih luas dari sebatas evaluasi. Saputra (2011) juga mengeluhkan kesalahpahaman supervisi dan praktik pengawasan yang salah, yang lebih menekankan sisi administratif alih-alih pengembangan kualitas guru yang lebih luas. Wanzare (2012) mengingatkan bahwa pemahaman yang baik dari supervisi akademik menjamin keberhasilan supervisi tersebut dan relasi antar supervisor dan supervisee juga akan lebih efektif terjalin. Oleh karena itu, diperlukan adanya sosialisasi mengenai supervisi yang lebih lengkap di awal, untuk menjelaskan program supervisi akademik yang lebih komprehensif dan membangun kerja sama yang baik antara supervisor dan para guru, seperti diingatkan oleh Lukum (2013) dan Ngatini \& Ismanto (2015).

Dasar hukum dan aturan yang melandasi dilaksanakannya supervisi akademik di PAUD Tunas Kasih adalah pedoman dari dinas pendidikan, seperti temuan Riyanto (2016) di lokasi penelitiannya, dan juga tuntutan dari manajemen sekolah YPKI Magelang. Namun demikian, pedoman dari manajemen sekolah masih belum lengkap, serupa dengan temuan Merukh dan Sulasmono (2016), sehingga penyusunan pedoman yang merinci kebutuhan dan tuntutan dalam pengembangan dan pelaksanaan supervisi akademik dibutuhkan.

Identifikasi kebutuhan diingatkan oleh Umiarso dan Gojali (2010) serta Sagala (2010), menjadi dasar untuk pemilihan dan perancangan teknik supervisi akademik yang tepat. Kepala sekolah maupun guru PAUD Tunas Kasih sudah menyebutkan beberapa kebutuhan dan kondisi di lapangan dan menjadikan kebutuhan tersebut sebagai dasar rancangan dan pelaksanaan supervisi akademik - berbeda dengan temuan Merukh \& Sulasmono (2016) yang mendapati kesalahan di mana supervisi akademik yang belum menjawab kebutuhan. Kebutuhan yang lebih spesifik atas masing-masing guru juga diingatkan Zepeda (2006) agar dilakukan, dan telah dilakukan di PAUD Tunas Kasih, seperti supervisi atas guru berlatarbelakang nonPAUD. Perlu diingat bahwa kondisi dan kebutuhan perlu ditinjau secara berkala untuk menjadi bahan perencanaan program.

\section{Evaluasi Input}

Dalam perencanaan dan perancangan program supervisi akademik, di awal tahun pembelajaran, kepala sekolah melibatkan guru untuk menyusun rencana program kerja sekolah secara luas, termasuk program supervisi akademik. Partisipasi guru tersebut merupakan hal yang perlu dilakukan seperti disampaikan Zepeda (2006), meskipun bentuk partisipasi dan kolaborasi dengan guru itu perlu diperluas. Perlu diperhatikan juga bahwa kegiatan supervisi akademik yang dirancang masih terpisah-pisah, karena kesalahpahaman terhadap konsep supervisi, sehingga ada kegiatan yang tidak tertuliskan dalam program kerja. Berbicara mengenai perencanaan kegiatan observasi, secara spesifik, sudah dilakukan dengan baik: kepala sekolah melibatkan guru dengan mengijinkan masingmasing guru menyampaikan atau memilih jadwal waktu mereka untuk diobservasiseperti ditemukan juga dalam penelitian Ngatini \& Ismanto (2015) dan Widodo (2014b). Program supervisi di PAUD Tunas Kasih juga didukung kesiapan para guru, dengan dukungan kerja sama tim dalam suasana yang suportif antar rekan sejawat, komunikasi yang terbuka dan kolaborasi dengan rekan sejawat. Sementara untuk melengkapi keterampilan supervisi serta membenahi kesalahpahaman kepala sekolah, 
pembekalan atau pelatihan pembekalan atau pelatihan perlu diadakan. Wanzare (2011) dan Sarfo \& Cudjoe (2016) menyoroti perlunya pelatihan bagi para pimpinan sekolah untuk menolong mereka dalam menjalankan fungsi supervisi di sekolah.

Pendanaan rogram supervisi akademik di PAUD Tunas Kasih berasal dari sumber interen, yaitu yayasan atau sekolah, maupun eksteren dari dinas, yang berbentuk dana bantuan operasional-dana bantuan serupa diungkapkan Riyanto (2016). Kepala sekolahatau malahan manajemen sekolah-perlu memfasilitasi pendanaan kegiatan yang akan diikuti guru, terkhusus mereka yang menunjukkan antusiasme untuk mengembangkan diri lewat kegiatan pelatihan atau seminar yang memang mendukung pengembangan pembelajaran.

Meskipun sarana-prasarana standar sudah tersedia, masih dilaporkan adanya keterbatasan fasilitas internet dan perangkat komputer. Ini perlu mendapat sorotan khusus, mengingat teknologi dan informasi di zaman ini memang mendukung pembelajaran. Keterbatasan alat juga dilaporkan Saputra (2011) sebagai kendala teknis dalam pelaksanaan pengawasan di sekolah, meskipun tidak dirincikan sarana prasarana apa. Bukubuku referensi yang juga telah tersedia, perlu diperbaharui dan ditambah koleksinya serta dimanfaatkan dengan lebih sebagai sumber ajar para guru.

\section{Evaluasi Proses}

Sebagian besar kegiatan dalam program supervisi akademik yang direncanakan telah dilaksanakan di PAUD Tunas Kasih, baik yang bersifat individual maupun kelompok, dengan beberapa perubahan dan penyesuaian dalam jadwal pelaksanaan. Dua kegiatan yang tidak terlaksana adalah kompetisi guru interen dan studi banding.

Teknik observasi kelas telah dilaksanakan secara terjadwal di PAUD Tunas Kasih, seperti dilaksanakan di beberapa sekolah lain (Widodo, 2014a; Widodo, 2014b; Riyanto, 2016; Merukh \& Sulasmono, 2016). Guru-guru PAUD Tunas Kasih sudah terbiasa diobservasi dan siap untuk berpartisipasi dalamnya, berbeda dengan laporan penelitian Lukum (2013) yang menyebutkan masih adanya guru yang takut untuk diobservasi. Usulan dilaksanakannya observasi tanpa pemberitahuan sebelumnya (unnancouced), perlu dipertimbangkan, dan instrumen observasi perlu diperbaiki.

Untuk teknik pelatihan, lokakarya atau seminar serta pertemuan kelompok guru, kepala sekolah telah berupaya mendorong partisipasi guru dengan memilih dan mengutus guru. Guru yang diutus juga berusaha bertanggung jawab menyusun laporan dan membagikan informasi ke rekan yang lain. Guru yang dinilai kompeten juga didorong untuk mengikuti kompetisi atau lomba. Upaya kepala sekolah untuk meningkatkan partisipasi, yang kembali bertujuan untuk peningkatan kompetensi, ini perlu diapresiasi.

Fleksibilitas dan penyesuaian, terhadap situasi dan kebutuhan, untuk pelaksanaan teknik di PAUD Tunas Kasih juga nampak, seperti pelaksanaan intervisitasi yang menyesuaikan situasi team-teaching, serta rapat guru yang dapat dilaksanakan menyesuaikan urgensi dan prioritas pembahasan. Selain itu, upaya untuk menciptakan suasana yang nyaman, alih-alih kaku dan formal, dengan memanfaatkan jam istirahat siang, juga mendukung efektifitas teknik rapat. Namun demikian, perlu diperhatikan perlu adanya pencatatan diskusi yang terjadi.

Konferensi dilaksanakan terutama sebelum dan sesudah observasi. Sesuai pengamatan dan hasil wawancara, para guru melaporkan adanya ada relasi yang saling mempercayai, umpan balik yang cukup konstruktif dan jelas, terutama berbicara tentang area-area yang perlu dikembangkan guru. Hal ini sesuai apa yang diingatkan oleh Range, Young dan Hvidston (2013). Kepala 
sekolah juga perlu mendorong dan memberikan kesempatan berefleksi bagi para guru (Martinez, Taut, \& Schaaf; 2016), seperti yang telah terlaksana di lokasi penelitian Ngatini \& Ismanto (2015). Hal ini membantu mereka memaknai apa yang telah didapat dari hasil observasi atau konferensi.

Kendala-kendala yang ditemui dalam proses pelaksanaan program supervisi akademik berhubungan dengan pengaturan jadwal dan prioritas pelaksanaan kegiatan, serupa dengan permasalahan yang menghambat pelaksanaan supervisi akademik yang diteliti Riyanto (2016). Meskipun kepala sekolah juga menyampaikan keluhan terhadap kesibukan tugas yang dimilikinya, seperti temuan Mawarni, Chiar \& Sukmawati (2017) dan Merukh \& Sulasmono (2016), namun kendala tersebut tidak mempengaruhi pelaksanaan supervisi akademik di PAUD Tunas Kasih karena adanya koordinasi dan pengaturan prioritas kegiatan. Kendala persetujuan atau perijinan dari pihak manajemen sekolah perlu ditangani dan dikomunikasikan dengan baik antara kedua pihak. Sementara kendala-kendala yang berasal dari pribadi guru-kemalasan, kelelahan, ketidakfokusan pekerjaan, dan kurangnya inisiatif-perlu dibahas sebagai bahan pembinaan guru. Keterbatasan internet dan sarpras mempengaruhi kelancaran penyusunan administrasi dan alat peraga yang mendukung pembelajaran.

Mengamati keterlibatan dan kesiapan para guru, yang berangkat dari kesadaran manfaat yang akan diperoleh (seperti juga ditemukan temuan Riyanto [2016]), hal tersebut perlu diapresiasi, karena itu menjadi faktor pendukung terlaksananya supervisi akademik yang efektif (Mawarni, Chiar \& Sukmawati, 2017). Pengaturan prioritas, koordinasi, dan partisipasi aktif juga menjadi pendukung terlaksananya supervisi akademik yang efektif.

Di sisi lain, meski pemahamannya konsep supervisi masih belum sempurna, kepala sekolah telah berupaya melaksanakan perannya sebagai supervisor dengan baik dan tegas. Dukungan, teguran atas kesalahan atau kelalaian tugas yang dilakukan, dan dorongan untuk terus berkembang diberikan oleh supervisor. Kepala sekolah berupaya membangun iklim sekolah yang kondusif dan mendorong adanya perubahan dan inovasi selain mengembangkan budaya kepercayaan dan keterbukaan - hal-hal yang dicatat Argiani \& Slameto (2015), Gaol \& Siburian (2018) dan Moye, Henkin, \& Egle (2005) dapat efektif meningkatkan efektivitas pendidikan dan kinerja guru. Perasaan cepat puas, merasa sudah berpengalaman, takut salah dan dicemoohkan, kehilangan semangat, mencari keamanan dan menghindari tantangan (Saputra, 2011)_yang kesemuanya menjadi faktor penghambattidak ditemukan dalam diri Kepala Sekolah. Menyoroti delegasi yang diberikan, perlu disusun tim supervisi, seperti dilaporkan Mawarni, Chiar \& Sukmawati (2017), karena tim tersebut justru dapat menolong tugas supervisi kepala sekolah dan mengefektifkan kegiatan yang dilaksanakan. Selain itu masukkan diberikan agar kepala sekolah memberikan feedback yang bukan sekedar informatif dan administratif, selain bahwa ekspektasi dari supervisor perlu disampaikan dengan jelas.

PAUD Tunas Kasih telah berusaha mendokumentasikan teknik-teknik supervisi yang terlaksana. Baik catatan tertulis serta laporan kegiatan telah tersusun, namun perlu dirapihkan. Sama halnya dengan foto-foto dokumentasi yang masih dimiliki para guru secara pribadi, namun mendukung pendokumentasian kegiatan, sebaiknya perlu dikoleksi dan dirapihkan secara kelompok untuk mendukung arsipan sekolah. Dokumen laporan observasi telah disusun secara rapih dan rutin, dengan catatan perlu adanya perbaikan instrumen panduan observasimeskipun sudah tersedia, dibandingkan dengan ketidaktersediaan instrumen atau tersedianya 
instrumen yang kurang baik atau tidak rinci, seperti dicatat dalam temuan penelitian Merukh \& Sulasmono (2016). Format atau pedoman lain, seperti format Penilaian Kinerja Guru (PKG) yang digunakan di tempat penelitian Widodo (2014a), dapat diadaptasi atau melengkapi item observasi yang sudah ada.

\section{Evaluasi Produk}

Program supervisi akademik yang dilaksanakan di PAUD Tunas Kasih dianggap efektif oleh para guru dan kepala sekolah dan menjawab kebutuhan yang telah diamati dalam evaluasi konteks. Dampak yang disampaikan tidak hanya berhubungan dengan pribadi dan tugas guru, namun juga secara kolektif terhadap situasi kerja dan citra sekolah. Hal ini berbeda dengan laporan dari Sarfo \& Cudjoe (2016) yang mengeluhkan rendahnya pelaksanaan dan efektifitas supervisi akademis di sekolahsekolah umum di Ghana.

Kepala sekolah dan guru PAUD Tunas Kasih mendaftarkan beberapa manfaat yang didapat dari supervisi akademik, seperti temuan Wanzare (2012), yaitu perbaikan kualitas dan kinerja guru dan peningkatan kolaborasi antar guru, yang semuanya berdampak pada peningkatan kualitas pembelajaran di kelas, dan penyamaan persepsi dan kontrol atau pengawasan yang lebih baik dari pimpinan. Kontrol juga berdampak pada ketertiban administrasi penunjang pembelajaran, serupa temuan Widodo (2014a). Namun demikian, seperti disoroti Widodo, hendaknya supervisor tidak hanya menitikberatkan pemeriksaan administrasi dalam melaksanakan supervisi. Guru juga menyadari terciptanya kesempatan untuk membangun jejaring dengan guru atau komunitas PAUD lain, dan ini menjadi dorongan untuk mereka lebih aktif terlibat dalam kegiatan seminar dan sejenisnya. Dampak jangka panjang berupa peningkatan kepercayaan dari pihak luar terhadap PAUD Tunas Kasih, yang juga berpengaruh pada promosi sekolah, dapat menjadi motivasi bagi kepala sekolah untuk melaksanakan supervisi akademik. Bagi para guru sendiri, kualitas dan reputasi yang unggul sebagai dampak supervisi akademik juga dapat menjadi pemacu semangat untuk terus mengembangkan diri.

Respon positif para guru nampak, berupa antusiasme untuk berpartisipasi dan kesiapan untuk mendapat masukan yang bermanfaat untuk pengembangan diri, serupa yang disampaikan para guru dalam penelitian Riyanto (2016). Guru PAUD Tunas Kasih juga mengapresiasi adanya kebebasan untuk mengungkapkan pemikiran dan memberi masukan. Kepala sekolah perlu memanfaatkan komunikasi dan keterbukaan tersebut untuk menanggapi respon negatif mereka, seperti keraguan untuk terlibat lebih aktif atau kekhawatiran untuk mengikuti seminar. Komunikasi serupa dapat menampung beban atau ketidakpuasan guru yang dirasakan karena belum dapat memikirkan implementasi ide yang didapat dari seminar.

Kembali, kepala sekolah perlu membangun komunikasi yang terbuka dan mencermati harapan dan masukan yang disampaikan para guru. Masukan terhadap kepala sekolah dalam menjalankan peran supervisor-nya menyoroti upaya memfasilitasi pengembangan kualitas dan melaksankan fungsi kontrol dan pengawasan. Usulan lain adalah agar supervisi dapat didelegasikan kepada guru lain atau dengan melibatkan pihak manajemen sekolah. Rekomendasi serupa disampaikan oleh Widodo (2014b) dan Slameto (2016) yang mengusulkan keterlibatan pengawas sekolah dari dinas pendidikan, atau melibatkan guru senior seperti yang ditemukan Riyanto (2016) atau Mawarni, Chiar, \& Sukmawati (2017) dan disarankan Zepeda (2006). Masukan untuk penambahan sarpras yang menunjang, secara spesifik adalah buku referensi dan fasilitas internet, juga diungkapkan oleh beberapa guru.

Evaluasi terhadap kegiatan maupun program perlu dilaksanakan, dan hal-hal yang perlu ditindaklanjuti sebagai temuan evaluasi 
tersebut juga perlu dicermati. Tindak lanjut yang dirancang berdasar hasil supervisi akademik sudah menjadi sorotan kepala sekolah, dan perlu dikomunikasikan dengan pihak manajemen sekolah agar juga dapat difasilitasi.

\section{SIMPULAN DAN SARAN}

\section{Simpulan}

Evaluasi Konteks. Program supervisi akademik di PAUD Tunas Kasih perlu diadakan, mempertimbangkan kondisi dan kebutuhan adanya peningkatan dan pengembangan kualitas guru-terkhusus berhubungan dengan proses belajarmengajar-dan menyesuaikan dengan kondisi kelas di tahun ajaran yang berlangsung maupun menjawab atau menghadapi tantangan dunia pendidikan yang ada. Usulan agar dilanjutkannya program ini perlu mengupayakan pemahaman konsep supervisi terlebih dahulu agar perencanaan dan perancangan program dan mekanisme pelaksanaan lebih lanjut dapat lebih terarah dan efektif.

Evaluasi Input. Perencanaan program telah berjalan baik sesuai kebutuhan dan dengan menyertakan beberapa ragam teknik supervisi akademik. Para guru siap untuk terlibat dalam program supervisi akademik di PAUD Tunas Kasih, namun perlu meningkatkan kesiapan atau keterampilan kepala sekolah dalam melaksanakan fungsi supervisi. Kesiapan para guru ini berangkat dari pemahaman mereka akan pentingnya dan manfaat supervisi akademik untuk mengembangkan diri dan makin memperlengkapi mereka untuk mengajar. Pendanaan serta sarpras yang ada sudah cukup mendukung dan tercukupi, dengan catatatan perlunya peningkatan fasilitas internet dan komputer.

Evaluasi Proses. Kegiatan-kegiatan yang direncanakan sebagian besar telah terlaksana dengan baik dengan penyesuaian kegiatan sesuai kondisi dan kebutuhan. Kendala yang ada, baik dari atau berhubungan dengan pribadi guru, kepala sekolah, manajemen sekolah, maupun sarana-prasarana, dapat ditangani dengan baik. Kesiapan dan partisipasi kepala sekolah maupun para guru mendukung pelaksanaan program supervisi akademik. Dokumentasi yang lengkap dan lebih terstruktur terhadap kegiatan yang telah diadakan perlu lebih ditingkatkan.

Evaluasi Produk. Program supervisi akademik di PAUD Tunas Kasih sudah memberikan dampak positif dan mencapai tujuan yang direncanakan terhadap pengembangan kualitas guru, juga secara kolektif terhadap citra sekolah sendiri. Para guru memberikan respon yang positif, dengan beberapa catatan sebaliknya atas respon negative yang kembali dapat ditangani atau perlu mendapat tindak lanjut dari kepala sekolah. Tindak lanjut telah direncanakan dan beberapa sudah langsung dilaksanakan atau disampaikan, dan evaluasi memberikan masukan untuk perbaikan dan pengembangan program supervisi akademik selanjutnya.

Oleh karena itu, mempertimbangkan keempat tahap evaluasi program supervisi akademik, penulis merekomendasikan kelanjutan program supervisi akademik, dengan beberapa catatan masukan dan penyesuaian untuk perbaikan program tersebut.

\section{Saran}

Pertama, kepada PAUD Tunas Kasih, berdasar evaluasi model CIPP, program supervisi akademik yang ada di PAUD Tunas Kasih perlu dilanjutkan, dengan beberapa pertimbangan dan perbaikan. Pemahaman konsep supervisi perlu kembali dimantapkan, baik oleh kepala sekolah maupun para guru. Pelatihan supervisi akademik kepada kepala sekolah, dan guru senior, oleh karena itu menjadi penting. Kebutuhan dan kondisi di PAUD Tunas Kasih perlu ditinjau secara berkala untuk dijadikan bahan perencanaan dan pengembangan program supervisi akademik, 
termasuk juga kebutuhan individu para guru. Penyusunan rencana dan perancangan teknikteknik supervisi akademik yang menjawab kebutuhan tersebut kemudian perlu dilakukan dengan lebih komprehensif dan menyeluruh. Fleksibilitas dan adaptasi dalam pelaksanaan program perlu terus diupayakan dalam menangani kendala yang muncul. Selain itu, kepala sekolah tetap perlu peka mewadahi dan mengapresiasi antusiasme para guru untuk terlibat dalam kegiatan yang dilaksanakan selain menjawab usulan dari mereka, seperti pelaksanaan unannounced observation, delegasi, dan self-reflection.

Rekomendasi untuk manajemen sekolah YPKI Magelang adalah adanya kebutuhan pelatihan supervisi akademik kepada kepala sekolah dan guru-guru senior. Pemahaman yang baik dan lebih lengkap menjamin efektifitas program (Moswela \& Mphale, 2015). Keterlibatan serta monitoring dari pihak manajemen sekolah juga diharapkan, sesuai usulan dari sekolah. Keterlibatan yang diusulkan termasuk memfasilitasi perijinan kegiatan dalam program supervisi akademik untuk menjawab kebutuhan pengembangan kualitas pendidikan dan guru. Selanjutnya, pedoman maupun instrumen yang mendukung program supervisi akademik juga perlu disediakan oleh pihak manajemen sekolah. Mengamati antusiasme dan partisipasi guru, pemberian penghargaan atau apresiasi perlu dipertimbangkan, seperti diusulkan oleh Lukum (2013). Seperti diingatkan Mette et al. (2015) dan Zepeda (2016), supervisi akademik tidak seharusnya terbatas pada evaluasi atau penilaian serta pencapaian standar yang tinggi, jadi manajemen sekolah perlu mendorong kepala sekolah dan guru untuk berkolaborasi lebih untuk tujuan peningkatkan mutu guru dan pendidikan.

Untuk penelitian sejenis selanjutnya, penelitian evaluatif ini masih terbatas dan spesifik untuk PAUD Tunas Kasih, seperti diingatkan McMillan (2008) dan dapat dilakukan penelitian di subyek atau lokasi lain. Temuan dan rekomendasi evaluasi dalam penelitian ini perlu ditinjau ulang, menyesuaikan kondisi dan kebutuhan lokal, sebelum diterapkan atau digeneralisasikan untuk sekolah lain. Penelitian selanjutnya dapat mengeksplorasi efektifitas supervisi akademik dengan melibatkan pihak pengelola sekolah, orang tua, dan siswa, terkhusus untuk pendidikan yang lebih tinggi, dan dengan penggunaan metode kuantitatif.

\section{DAFTAR PUSTAKA}

Aaronson, D., Barrow, L., \& Sander, W. 2007. Teachers and student achievement in the Chicago public high schools. Journal of Labor Economics, 25, 95-135.

Alatas, H. 2013. Early childhood education and development services in Indonesia. Dalam Suryadarma, D., \& Jones, G. W. (Eds.). Education in Indonesia. Singapore: Institute of Southeast Asian Studies.

Argiani, A., \& Slameto, S. 2015. Supervisi Kunjungan Kelas untuk Meningkatkan Kompetensi Pedagogik Guru SDN Cukil 01, Tengaran, Kabupaten Semarang. Kelola: Jurnal Manajemen Pendidikan, 2(1), 1-11. https://doi.org/10.24246/j.jk.2015.v2.i1 .p1-11

Arikunto, S. 2012. Dasar-Dasar Evaluasi Pendidikan, Edisi Kedua. Jakarta: Bumi Aksara.

Arikunto, S., \& Jabar, C. S. A. 2010. Evaluasi Program Pendidikan: Pedoman Teoritis Praktis bagi Mahasiswa dan Praktisi Pendidikan. Jakarta: Bumi Aksara.

Arikunto, S., \& Yuliana, L. 2012. Manajemen Pendidikan. Yogyakarta: Aditya Media.

Brown, G. B. 2002. Guiding faculty to excellence: Instructional supervision in 
Evaluasi Program Supervisi Akademik di PAUD Swasta | Daniel Kurniawan, dkk.

the Christian school. Purposeful Design Publications.

Dwikurnaningsih, Yari. 2017. Evaluasi Program Kelas Olahraga di SMP Negeri 3 Salatiga. Repository Perpustakaan Universitas. Salatiga: Magister Manajemen Pendidikan UKSW.

Egwu, S. O. 2015. Principals' Performance in Supervision of Classroom Instruction in Ebonyi State Secondary Schools. Journal of Education and Practice, 6(15), 99-105.

Fitzpatrick, J. L., Sanders, J. R., \& Worthen, B. R. 2012. Program Evaluation: Alternative approaches and practical guidelines, $4^{\text {th }}$ ed.. New Jearsey: Pearson Education.

Gaol, N.T.L., \& Siburian, P. 2018. Peran Kepala Sekolah Dalam Meningkatkan Kinerja Guru. Kelola: Jurnal Manajemen Pendidikan, 5(1), 66-73. https://doi.org/10.24246/j.jk.2018.v5.i1 .p66-73

Garrett, R., \& Steinberg, M. P. 2015. Examining teacher effectiveness using classroom observation scores: Evidence from the randomization of teachers to students. Educational Evaluation and Policy Analysis, 37(2), 224-242.

Imron, A. 2011. Supervisi Pembelajaran Tingkat Satuan Pendidikan. Jakarta: Bumi Aksara.

Kartono, S. 2009. Sekolah bukan pasar: catatan otokritik seorang guru. Jakarta: Penerbit Buku Kompas.

Lukum, A. 2013. Evaluation of science learning supervision on secondary schools. International Journal of Education, 5(4), 61-81.

Martinez, F., Taut, S., \& Schaaf, K. 2016. Classroom observation for evaluating and improving teaching: An international perspective. Studies in Educational Evaluation, 49, 15-29. doi:10.1016/j.stueduc.2016.03.002

Mawarni, R., Chiar, H. M., \& Sukmawati, H. 2017. Supervisi Akademik di Sekolah Menengah Atas Negeri 1 Pemangkat Kabupaten Sambas. Jurnal Pendidikan dan Pembelajaran, 6(1).

McMillan, J. H. 2008. Educational Research: Fundamentals for the customer, $5^{\text {th }} \mathrm{Ed}$. Pearson.

Memduhoglu, H. B. 2012. The issue of education supervision in Turkey in the views of teachers, administrators, supervisors, and lecturers. Educational Sciences; Theory and Practice, 12(1), 149-156.

Merukh, N., \& Sulasmono, B.S. 2016. Pengembangan Model Supervisi Akademik Teknik Mentoring Bagi Pembinaan Kompetensi Pedagogik Guru Kelas. Kelola: Jurnal Manajemen Pendidikan, 3(1), 30-48. https://doi.org/https://doi.org/10.24246/ j.jk.2016.v3.i1.p30-48

Mette, I. M., Range, B. G., Anderson, J., Hvidston, D. J., \& Nieuwenhuizen, L. 2015. Teachers' Perceptions of Teacher Supervision and Evaluation: A Reflection of School Improvement Practices in the Age of Reform. Education Leadership Review, 16(1), 16-30.

Miles, M. B., Huberman, A. M., \& Saldana, J. 2014. Qualitative Data Analysis: A methods sourcebook, $3^{\text {rd }}$ Ed. Sage.

Minarti, S. 2011. Manajemen Sekolah: Mengelola Lembaga Pendidikan Secara Mandiri. Yogyakarta: Ar-Ruzz Media.

Moswela, B., \& Mphale, L. M. 2015. Barriers to clinical supervision practices in Botswana schools. Journal of 
Kelola: Jurnal Manajemen Pendidikan, Vol. 5, No. 2, Juli-Desember 2018

Education and Training Studies, 3(6), 61-70.

Moye, M.J., Henkin, A.B., \& Egley, R.J., 2005. Teacher-principal relationships: Exploring linkages between empowerment and interpersonal trust. Journal of Educational Administration, 43(3), 260-277, https://doi.org/10.1108/095782305105 94796.

Mukhtar \& Iskandar. 2009. Orientasi Baru Supervisi Pendidikan. Jakarta: GP Press.

Mulyasa, E. 2012. Manajemen dan kepemimpinan kepala sekolah. Jakarta: Bumi Aksara.

Munthe, A. P. 2015. Pentingnya Evaluasi Program di Institusi Pendidikan: Sebuah Pengantar, Pengertian, Tujuan dan Manfaat. Scholaria: Jurnal Pendidikan Dan Kebudayaan, 5(2), 1-14.

Ngatini, N., \& Ismanto, B. 2015. Pengelolaan Supervisi Akademik Kepala Sekolah di Sekolah Dasar Negeri Kota Semarang. Kelola: Jurnal Manajemen Pendidikan, 2(2), 127-138. https://doi.org/10.24246/j.jk.2015.v2.i2 .p127-138

Pidarta, M. 2009. Supervisi Pendidikan Kontekstual. Jakarta: Rineka Cipta.

Priansa, D.J., \& Setiana, S.S. 2018. Manajemen dan Supervisi Pendidikan. Bandung: Pustaka Setia.

Range, B.G., Young, S., \& Hvidston, D. 2013. Teacher perceptions about observation conferences: what do teachers think about their formative supervision in one US school district? School Leadership \& Management, 33 (1), 61-77.

Riyanto. 2016. Evaluasi Program Supervisi Akademik Kepala Sekolah dapat Meningkatkan Kinerja Mengajar Guru
SD Negeri 1 Tegorejo, Kecamatan Pengandon, Kabupaten Kendal. (Tesis, tidak diterbitkan). Program Pascasarjana, Universitas Kristen Satya Wacana, Salatiga.

Rockoff, J. E. 2004. The impact of individual teachers on student achievement: Evidence from panel data. American Economic Review, 94, 247-252.

Sagala, S. 2010. Supervisi Pembelajaran dalam Profesi Pendidikan. Bandung: Alfabeta.

Saputra, Y. M. 2011. Model Pengawasan Pembelajaran Pendidikan Jasmani di SD. Cakrawala Pendidikan, (3), 474489.

Sarfo, F. K., \& Cudjoe, B. 2016. Supervisors' Knowledge and Use of Clinical Supervision to Promote Teacher Performance in basic schools. International Journal of Education and Research, 4(1).

Slameto. 2016. Supervisi Pendidikan oleh Pengawas Sekolah. Kelola: Jurnal Manajemen Pendidikan, 3(2), 192-206. https://doi.org/10.24246/j.jk.2016.v3.i2 .p192-206

Stronge, J. H., Richard, H. B., \& Catano, N. 2013. Kualitas Kepala Sekolah yang Efektif. Jakarta: PT Indeks.

Suhardan, D. 2010. Supervisi Profesional: layanan dalam meningkatkan mutu pembelajaran di era otonomi daerah. Bandung: Alfabeta.

Sukardi, H. M. 2008. Evaluasi Pendidikan Prinsip dan Operasionalnya. Jakarta: Bumi Aksara.

Suryadarma, D., \& Jones, G.W. 2013. Meeting the education challenge. Dalam Suryadarma, D., \& Jones, G. W. (Eds.). Education in Indonesia. Singapore: Institute of Southeast Asian Studies. 
Evaluasi Program Supervisi Akademik di PAUD Swasta | Daniel Kurniawan, dkk.

Tatang, $\quad$ S. $2016 . \quad$ Supervisi Pendidikan. Bandung: Pustaka Setia.

Umiarso \& Gojali, I. 2010. Manajemen Mutu Sekolah di Era Otonomi Pendidikan. Yogyakarta: IRCiSoD.

Wanzare, Z. 2012. Instructional supervision in public secondary schools in Kenya. Educational Management Administration \& Leadership, 40(2), 188-216.

Widodo, T. 2014a. Evaluasi Program Implementasi Supervisi Akademik di Gugus Dwijawiyata, Kecamatan Magelang Tengah, Kota Magelang. (Tesis, tidak diterbitkan). Program
Pascasarjana, Universitas Kristen Satya Wacana, Salatiga.

Widodo, T. 2014b. Supervisi Kunjungan Kelas dalam Meningkatkan Kinerja Guru IPA SMP Negeri 1 Bandungan. (Tesis, tidak diterbitkan). Program Pascasarjana, Universitas Kristen Satya Wacana, Salatiga.

Wiersma, W., \& Jurs, S. G. 2005. Research Methods in Education: An introduction, 9th ed. Pearson Education.

Zepeda, S.J. 2006. High stakes supervision: we must do more. International Journal of Leadership in Education: Theory and Practice, 9:1, 61-73, DOI: 10.1080/13603120500448154. 